\title{
Introduction to the Special Issue on Enactivism: Theory and Performance
}

\section{Kevin Ryan ${ }^{1}$}

Accepted: 29 September 2021 / Published online: 19 October 2021

(C) The Author(s), under exclusive licence to Springer Nature B.V. 2021

Enactive approaches to cognition continue to be developed in ways that are informed by phenomenology, pragmatism, and ecological psychology. Recent work in this area has fostered theory development and applications across a number of disciplines and topics. In this issue we include papers by Hanne De Jaegher, Ezequiel Di Paolo, Simon Høffding, Katsunori Miyahara, and Mog Stapelton first presented at a conference on Enactivism: Theory and Performance at the University of Memphis in March 2018, organized by Kevin Ryan, Albert Newen, and Shaun Gallagher. This conference was supported by the Humboldt Foundation's Anneliese Maier Research Award, the Lillian and Morrie Moss Chair of Excellence in Philosophy at the University of Memphis, the Cognitive Science Program at the Institute for Intelligent Systems at the University of Memphis, and the Australian Research Council's Minds in Skilled Performance project at the University of Wollongong. Papers on the same theme have been contributed by Guido Baggio, Alan Jurgens, Susanne Ravn, Abootaleb Safdari Sharabiani, and by Alva Noë, with a response by Daniel Hutto and Erik Myin.

Publisher's note Springer Nature remains neutral with regard to jurisdictional claims in published maps and institutional affiliations.

Kevin Ryan

kryan30@utk.edu

1 Department of Philosophy, University of Tennessee Knoxville, Knoxville, TN 37996-0480, USA 